\title{
Pelaksanaan Usahatani Tebu Pasca Pencabutan Inpres Nomor 5 Tahun 1997 (Program Pengembangan Tri) Di Propinsi Daerah Istimewa Yogyakarta
}

\author{
Unggul Priyadi \\ F E Universitas Islam Indonesia Yogyakarta
}

Email: unggul@,fe.uii.ac.id

\begin{abstract}
Tujuan penelitian yang akan dicapai adalah menganalisis faktor-faktor yang mempengaruhi peluang petani menentukan pilihan kelembagaan usahatani tebu, menganlisis secara deskriptif variabel-variabel yang mempengaruhinya serta mengkaji variabel yang mendorong keberlangsungan eksistensi usaha PG Maduksimo. Temuan penelitian yang diperoleh antara lain peluang petani menentukan pilihan kelembagaan usahatani tebu secara serempak dipengaruhi oleh luas lahan, rendemen, pendidikan responden, pengalaman responden dan biaya menjalankan usahatani tebu. Disamping itu, ternyata pasokan tebu dari luar wilayah Propinsi DIY mempunyai peranan yang signifikan untuk keberlangsungan giling PG. Implikasi kebijakan yang dapat dapat ditempuh untuk mendorong petani menjalankan usahtani tebu, tidak cukup hanya memberi insentif kepada para pemilik lahan tetapi juga diperlukan dorongan semua pihak dalam pengembangan usahatani tebu serta dorngan dalam menjalin kerjasama dengan berbagai pihak dalam menyediakan areal usahatani tebu.
\end{abstract}

Kata kunci: Inpres No 5 Tahun 1998, kelembagaan usahatani tebu, TR Mandiri, TR KSU, TR Kemitraan dan multinomial logistik.

\section{PENDAHULUAN}

Pangan merupakan salah satu kebutuhan manusia yang paling azasi, sebagaimana dituangkan dalam Universal Declaration of Human Right Tahun 1948 dan Undang-Undang RI Nomor 7 Tahun 1996 tentang pangan, sehingga ketersediaan pangan bagi masyarakat harus selalu terjamin (Suryana, 2004). Dalam perkembangan globalisasi dan liberalisasi perdagangan, beberapa komoditas pangan menjadi komoditas strategis disebabkan ketidakpastian dan ketidakstabilan produksi. Dalam konteks ini ketersediaan pangan suatu negara tidak hanya mengandalkan produksi nasional tetapi juga pasar dunia. Sebagian besar negara-negara di dunia menetapkan ketahanan pangan untuk kepentingan dalam negerinya.

Dalam konteks kedaulatan pangan nasional menjadi suatu hal yang ironis beberapa komoditas yang pernah menjadi andalan ekspor saat kini harus diimpor, seperti: beras, gula, kedelai dan jagung. Salah satu faktor penyebab terjadinya hal tersebut adalah semakin menurunnya produktivitas gula nasional, saat ini menjadi importir gula yang cukup besar (Suryana, 2003).

Dalam persepektif historis, Indonesia pernah mengalami era kejayaan industri gula pada tahun 1930-an, produktivitas habluh 14,8 ton/ha dan rendemen mencapai $11 \%-13,8 \%$. Dengan produksi puncak mencapai sekitar 3 juta ton, ekspor gula pernah mencapai sekitar 2,4 juta ton. Kini, Indonesia merupakan salah satu importir gula terbesar di dunia dengan volume impor ratarata sekitar 1,5 juta ton pada dekade terakhir (Susila dan Supriono, 2006).

Adanya impor gula menjadi strategis dalam memenuhi kebutuhan konsumsi domestik, akibat terjadinya kesenjangan produksi dan konsumsi gula nasional. Hal ini menjadikan perdagangan internasional sangat penting dalam mengamankan neraca nasional. Perkembangan konsumsi, produksi dan impor gula disajikan tabel berikut: 
Tabel 1: Produksi, Konsumsi dan Impor Gula Indonesia Tahun 1996-2007

\begin{tabular}{|c|c|c|c|}
\hline Tahun & Produksi (000 ton) & Konsumsi (000 ton) & Impor \\
\hline 1996 & $2.094,2$ & $3.069,9$ & 975,8 \\
\hline 1997 & $2.190,0$ & $3.363,3$ & $1.364,6$ \\
\hline 1998 & $1.491,6$ & $3.300,0$ & $1.811,7$ \\
\hline 1999 & $1.498,8$ & $3.360,0$ & $2.187,1$ \\
\hline 2000 & $1.693,8$ & $3.300,0$ & $1.600,0$ \\
\hline 2001 & $1.713,3$ & $3.360,0$ & $1.600,0$ \\
\hline 2002 & $1.755,1$ & $3.300,0$ & $1.544,0$ \\
\hline 2003 & $1.800,0$ & $3.200,0$ & $1.400,0$ \\
\hline 2004 & $2.051,6$ & $3.281,9$ & $1.230,3$ \\
\hline 2005 & $2.219,8$ & $3.324,7$ & $1.104,9$ \\
\hline 2006 & $2.266,8$ & $3.363,0$ & $1.231,4$ \\
\hline 2007 & $2.400,0$ & $3.344,8$ & $1.333,9$ \\
\hline
\end{tabular}

Sumber : Litbang Kompas, Departemen Pertanian, 2007

Permasalahan yang berkait langsung dengan usahatani tebu mencakup: turunnya produksi dan produktivitas, insentif harga yang diterima petani kurang merangsang, perbaikan budidaya terhambat, efisiensi pabrik gula, tataniaga gula dan aspek perdagangan internasional (Sekretariat DGI, 2004). Turunnya produksi dan produktivitas gula disebabkan berbagai faktor seperti: budidaya tebu di bawah standar, penanaman di bawah masa optimal, mayoritas lahan tebu adalah lahan kering, proporsi tanaman keprasan lebih besar (lebih dari 60\%), mutu dan kesehatan bibit tidak optimal, sebagian besar varietas yang digunakan masih varietas lama, sistem tebang angkut tidak optimal, adanya gangguan hubungan antara PG dan petani. (Sekretariat DGI, 2004).

Salah satu permasalahan yang terjadi di wilayah kerja Pabrik Gula Madukismo adalah jumlah produksi gula yang belum mampu mencukupi kebutuhan masyarakat DIY. Permasalahan industri gula yang terjadi saat ini tidak terlepas dengan pelaksanaan Inpres Nomor 5 Tahun 1998 tentang Penghentian Pelaksanaan Inpres No. 9 Tahun 1975 yang diperkuat Inpres No. 5 Tahun 1997 (Program Pengembangan Tebu Rakyat). Sebagai respons kebijakan pemerintah tersebut PG Madukismo melakukan inovasi kelembagaan sebagai upaya memberikan dorongan para petani lebih tertarik mengusahakan tanaman tebu.

Dalam upaya mengamankan pasokan tebu, pada tahun 1998 PG Madukismo mengadakan inovasi kelembagaan berupa kerjasama dengan petani dalam menjalankan usahatani tebu dan memberikan jaminan pendapatan minimum (JPM). Petani yang memeperoleh JPM adalah petani yang melakukan adopsi inovasi kelembagaan dengan menjalankan usahtani tebu rakyat Kemitraan (TR Kemitraan) dan usahatani tebu kerjasama usaha (TR KSU). Rincian Luas areal didasarkan pada jenis kelembagaan usahatani disajikan pada tabel 3 berikut:

Tabel 2: Luas Lahan dan Produksi Berdasar Jenis Kelembagaan Usahatani Tebu

\begin{tabular}{|c|r|r|r|r|r|r|}
\hline \multirow{2}{*}{ Tahun } & \multicolumn{2}{|c|}{ TR Mandiri } & \multicolumn{2}{c|}{ TR KSU } & \multicolumn{2}{c|}{ TR Kemitraan } \\
\cline { 2 - 7 } & $\begin{array}{c}\text { Luas } \\
\text { Lahan } \\
(\mathrm{ha})\end{array}$ & $\begin{array}{c}\text { Produksi } \\
(\mathrm{ku})\end{array}$ & $\begin{array}{c}\text { Luas Lahan } \\
(\mathrm{ha})\end{array}$ & $\begin{array}{c}\text { Produksi } \\
(\mathrm{ku})\end{array}$ & $\begin{array}{c}\text { Luas Lahan } \\
(\mathrm{ha})\end{array}$ & $\begin{array}{c}\text { Produksi } \\
(\mathrm{ku})\end{array}$ \\
\hline 1998 & $1.080,84$ & 1.131 .590 & - & - & $3.345,81$ & 2.638 .684 \\
\hline 1999 & 875,66 & 874.542 & 146,08 & 130.141 & $2.983,85$ & 1.434 .475 \\
\hline 2000 & 746,14 & 821.823 & 230,60 & 208.664 & $3.311,19$ & 2.046 .785 \\
\hline 2001 & 624,90 & 880.310 & 114,01 & 89.768 & $3.033,97$ & 1.740 .318 \\
\hline 2002 & 950,32 & 789.231 & 146,79 & 139.321 & $3.132,78$ & 1.695 .120 \\
\hline 2003 & $1.098,59$ & 629.490 & 194,50 & 167.302 & $2.989,55$ & 1.671 .087 \\
\hline 2004 & $1.285,80$ & 1.924 .349 & 116,67 & 110.296 & $2.583,79$ & 1.411 .059 \\
\hline 2005 & $2.562,99$ & 2.901 .937 & 166,77 & 139.533 & $2.636,21$ & 1.590 .862 \\
\hline 2006 & $3.060,72$ & 3.110 .972 & 309,11 & 255.034 & $2.538,38$ & 1.357 .066 \\
\hline 2007 & $4.100,11$ & 3.707 .066 & 336,59 & 295.847 & $2.563,43$ & 1.597 .194 \\
\hline
\end{tabular}

Sumber: PG Madukismo, 2008 
Semenjak pelaksanaan Inpres Nomor 5 Tahun 1998 dan PG Madukismo melakukan inovasi kelembagaan usahatani tebu, respons para petani sangat signifikan dalam pelaksanaan usahatani tebu. Salah satu daya tarik petani menjalankan usahatani tebu melalui adopsi inovasi kelembagaan adalah adanya JPM dari PG Maduksimo yang diberikan kepada petani yang menjalankan usahatani TR KSU dan TR Kemitraan. Bagi petani hal ini dapat meminimalisasi resiko jika terjadi gagal panen atau hasilnya kurang baik. Para petani tebu yang memasok tebu ke PG Madukismo di wilayah Propinsi DIY tersebar di 4 kabupaten yakni: Kabupaten Bantul, Gunung Kidul, Kulon Progo dan Sleman serta beberapa kabupaten di Propinsi Jawa Tengah, yaitu: Kabupaten Kebumen, Purworejo, Magelang dan Temanggung.

Berdasarkan latar belakang diatas tujuan penelitian yang akan dicapai adalah menganalisis faktor-faktor yang mempengaruhi peluang petani menentukan pilihan kelembagaan usahatani tebu, menganlisis secara deskriptif variabel-variabel yang mempengaruhinya serta mengkaji variabel yang mendorong keberlangsungan eksistensi usaha PG Maduksimo sebagai respon Penghentian Pelaksanaan Inpres No. 9 Tahun 1975 dan diperkuat Inpres No 5 Tahun 1997

\section{Tinjauan Pustaka}

\section{Aspek Kelembagaan dan Kelayakan Usaha}

Institusi digolongkan dua yang jenis adalah institusi informal dan formal (North, 1991, p.97. Bank Dunia, 2002. p.6). Institusi formal meliputi aturan tertulis pada peraturan perundangundangan oleh pemerintah. aturan yang disusun (UU) dan yang diadopsi oleh badan partikulir, dan publik dan operasi organisasi pribadi di bawah hukum publik. Institusi informal, yang sering beroperasi di luar sistem sah tentang undang-undang formal, mencerminkan kode sosial yang tidak tertulis seperti norma-norma sosial.

Sudaryanto dan Simatupang (1993) menyatakan bahwa komoditas pertanian umumnya merupakan barang dagangan dan salah satu kriterianya layak secara ekonomi dan finansial. Kelayakan ekonomi, tingkat keunggulan komparatif merupakan ukuran daya saing potensial yang akan dicapai apabila perekonomian tidak mengalami distorsi. Daya tarik pasar pada dasarnya pemikiran mengurangi peran pemerintah dan meningkatkan kemandirian petani dan pelaku agribisnis lain

Kemampuan institusi berkoordinasi, mengendalikan interdependensi antar partisipan (pemilik input) ditentukan oleh kemampuan institusi mengendalikan sumber interdependensi yang merupakan karakteristik dari barang, seperti resiko, ketidakpastian dan biaya transaksi. Kelembagaan menggambarkan interaksi unsur-unsur sistem kelembagaan yang di dalamnya mengorganisasikan komponen yang saling interdependensi. Secara skematis digambarkan (http: www.encycogov.com/B11 Research Traditions/TCE/9/24/2005): 


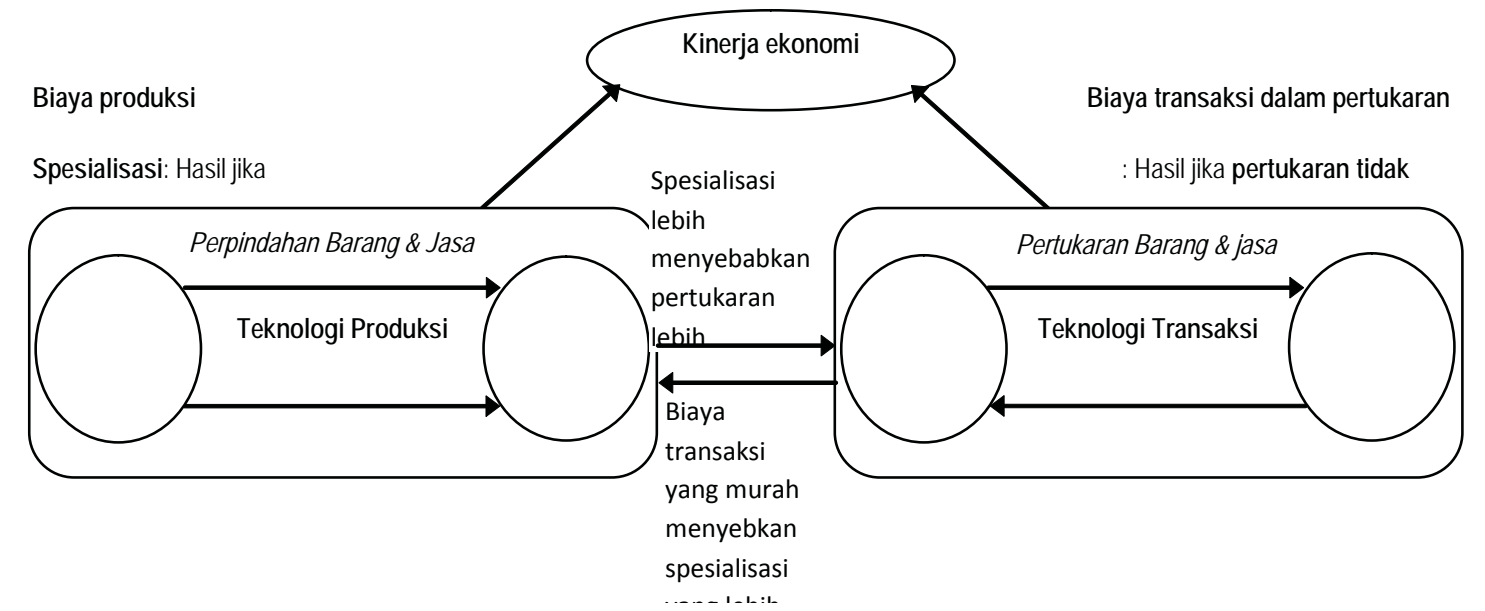

Gambar 1: Keterkaitan Berbagai Komponen dalam Kinerja Ekonomi

Kinerja ekonomi dipengaruhi dan terkait dengan berbagai aspek yang saling interdependensi. Dalam produksi modern memerlukan, dan spesialisasi yang menyebabkan pertukaran antar agen dan prinsipal serta spesialisasi untuk efisien. Teknologi transaksi seperti kontrak dan undang-undang adalah tidak sempurna dan oleh karena itu pertukaran dihubungkan dengan biaya transaksi. Makin baik teknologi, lebih sedikit biaya transaksi dan semakin banyak yang dibayar untuk spesialisasi lebih lanjut. Semakin banyak produksi yang terspesialisasi maka semakin banyak barang dan jasa yang ditukar dan menyebabkan biaya transaksi naik. Untuk itu perlu cek dan keseimbangan dalam teknologi transaksi dan produksi yang menentukan tingkat spesialisasi yang optimal dan pertukaran.

Aspek-aspek kinerja ekonomi dalm suatu lembaga disebabkan oleh berbagai faktor, yakni; (Milgrom dan Roberts, 1992):

1. Kondisi Lingkungan

2. Kondisi Tingkah Laku

3. Kondisi Produksi

4. Konsep Ekonomi Utama

5. Dasar Pelaku Ekonomi

6. Faktor Produksi dan Keluaran

7. Pertukaran, Produksi dan Teknologi

\section{Biaya Transaksi}

Biaya transaksi adalah biaya dalam melakukan pertukaran, apakah antara perusahaan di pasar atau transfer sumberdaya antara tahap-tahap pada perusahaan yang terintegrasi secara vertikal, ketika asumsi neo klasik yang sempurna dan tanpa biaya informasi dilongggarkan. Pendekatan biaya transaksi memperlakukan transaksi perusahaan. Berbeda dalam sistem ekonomi bebas yang telah dijelaskan teori neoklasik, pendekatan biaya transaksi mengakui transaksi terjadi bukan tanpa pemisahan biaya yang muncul dari intervensi dalam perusahaan sebagai biaya transaksi (Hobbs: Supply Chain Management: Vol 1 :No2: 1996).

Collins dan Fabozzi, 1991 (dalam Yustika, 2006) menjelaskan konsep biaya transaksi yang kompleks diderivasi dalam bentuk variabel-variabel yang mudah untuk diukur melalui formulasi sebagai berikut:

1. Biaya transaksi $=$ biaya tetap $(B T)+$ biaya variabel $(B V)$ 
2. Biaya tetap $=$ komisi + transfer fees + pajak;

3. Biaya variabel = biaya eksekusi + biaya oportunitas;

4. Biaya eksekusi $=$ price impact + market timing costs;

5. Biaya oportunitas $=$ hasil yang diinginkan - pendapatan aktual - biaya eksekusi - BT

Keterkaitan biaya transaksi dengan kelembagaan mempunyai makna strategis sebagai indikator tingkat efisiensi. Indikator efisiensi kelembagaan diamati dari tinggi rendahnya biaya transaksi yang muncul dari transaksi ekonomi. Semakin rendah biaya transaksi menunjukkan kelembagaan yang efisien, demikian sebaliknya. (Yeager, 1999, dalam Yustika, 2006).

\section{Adopsi Inovasi}

Adopsi inovasi mempunyai pengertian kompleks dan dinamis. Proses adopsi inovasi menyangkut pengambilan keputusan yang di dalamnya terdapat banyak faktor yang mempengaruhinya. Rogers dan Shoemaker (1971) mendefinisikan poses pengambilan keputusan melakukan adopsi inovasi, adalah:

the mental process of an innovation to a decision to adopt or to reject and to confirmation of this decision....

Berdasarkan definisi tersebut terdapat elemen penting dalam proses adopsi inovasi, yaitu sikap mental untuk melakukan adopsi inovasi dan adanya konfirmasi keputusan yang diambil. Berlangsungnya adopsi inovasi merupakan suatu proses berdasarkan dimensi waktu. Dua hal yang menjadi pertimbangan adopsi inovasi yaitu identitas calon adopter dan persepsi situasi yang dimiliki.

Cepat tidaknya proses adopsi inovasi secara individu tergantung dari faktor internal adopter, latar belakang sosial, ekonomi, budaya atau polilik Hal penting lain yang mempengaruhi adopsi inovasi individu adalah: (Soekartawi, 2005).

1. Umur

2. Pendidikan

3. Keberanian mengambil resiko

4. Pola hubungan

5. Sikap terhadap perubahan

6. Motivasi berkarya

7. Fatalisme

\section{Pengambilan Keputusan Manajerial}

Proses pengambilan keputusan manajerial, manajer tidak mengetahui hasil pasti pilihan tindakan yang mungkin diambil. Pengembalian investasi jangka panjang tergantung pada kondisi ekonomi masa depan, tingkat persaingan, cita rasa konsumen, teknologi, iklim politik, dan faktor lain yang tidak bisa diramalkan secara sempurna. Dalam situasi ini perusahaan menghadapi resiko atau ketidakpastian (Salvatore, 2005, Suparanto, 2005).

Sikap seseorang dalam menghadapi persoalan yang mengandung resiko dapat dibedakan menjadi tiga, yaitu: sikap menghindari resiko, netral atau sikap pengambil resiko (Mangkusubroto,1982; Soepranto, 2007). 


\section{METODE PENELITIAN}

\section{Dimensi Penelitian}

Penelitian ini merupakan kombinasi antara penelitian menerangkan (explanatory research) dan penelitian deskriptif. Penelitian deskriptif memberikan gambaran lebih mendalam tentang gejala-gejala sosial tertentu atau aspek kehidupan pada masyarakat yang diteliti. Pendekatan tersebut dapat mengungkapkan secara hidup kaitan antara berbagai gejala sosial, dimana hal tersebut tidak dapat dicapai oleh penelitian yang bersifat menerangkan (Singarimbun dan Effendi, 1995; Hadari, 1998; Arikunto:1997).

Desain penelitian yang digunakan adalah metode kuantitatif sehingga pelaksanaan penelitian menggunakan paradigma positivist yang menempatkan dimensi obyektif dalam asumsi epistimologinya. Penggunaan metode deduktif ditunjukkan untuk menguji hipotesis berdasarkan data empiris. Proses deduksi dianggap valid jika tidak mungkin membuat kesimpulan yang salah jika semua premisnya benar. Konklusi hanya diterima jika semua premisnya benar dan valid (Arikunto,1997, Jogiyanto,2004).

\section{Jenis Data dan Metoda Penentuan Sampel}

Data yang dianalisis merupakan data primer data sekunder. Data sekunder dikumpulkan dari berbagai sumber utama dan sumber pendukung seperti Dinas Pertanian dan Perkebunan Propinsi DIY serta Dinas Pertanian dan Perkebunan Kabupaten serta berbagai publikasi relevan dengan pelaksanaan usahatani tebu. Pengambilan data primer dilakukan terhadap petani di wilayah Propinsi DIY dengan cakupan sebaran yang meliputi: Kabupaten Bantul, Gunung Kidul, Sleman dan Kulon Progo.

Elemen populasi meliputi petani yang menjalankan usahatani tebu dengan kelembagaan usahatani TR Mandiri, TR Kemitraan dan TR KSU. Metode penentuan sampel yang digunakan adalah Stratified Random Sampling. Pemilihan metode didasarkan pada tujuan untuk mencapai keterwakilan masing-masing kelompok sampel dan tingkat acak pada pengambilan data. Masing-masing kelompok sampel dipilih secara random sesuai dengan proporsinya.

Jumlah sampel minimal yang diambil dalam penelitian, digunakan formulasi perhitungan (Sedarmayanti dan Hidayat, 2002)

$$
\begin{aligned}
& n=\frac{\sum \frac{n_{i}{ }^{2} s_{i}^{2}}{w_{i}}}{\left[\frac{\mathrm{d}}{Z_{\mathrm{a} / 2}}\right]^{2} N^{2}+\sum n_{i} s_{i}^{2}} \\
& w_{i}=\frac{n_{i}}{N}=\frac{n_{i} s_{i}}{\sum n_{i} s_{i}}
\end{aligned}
$$

Keterangan:

$$
\begin{aligned}
& \mathrm{d}=\text { bound of error }=0,2 \\
& \mathrm{a} \quad=\text { tingkat nyata (kesalahan) } \alpha 5 \% \\
& Z_{\mathrm{a}}=\text { nilai } Z \text { dibawah kurva normal pada tingkat nyata } \alpha 5 \% \\
& n_{i}=\text { jumlah populasi pada kelompok ke i } \\
& \mathrm{N}=\text { jumlah populasi } \\
& s_{i}=\text { simpangan baku strata ke i }
\end{aligned}
$$


Jumlah sampel yang diambil dari petani tebu yang menjalankan usahatani pada musim giling tahun 2007 pada wilayah Kerja PG Madukismo sejumlah 133 responden dengan rincian petani tebu dalam kelembagaan TR Mandiri 64 responden, TR KSU sebanyak 10 responden dan TR Kemitraan 59 responden.

\section{Analisis Data}

Metode analisis yang digunakan adalah analisis deskriptif dan kuantitatif. Analisis deskriptif mencakup pembahasan variabel yang yang digunakan dalam penelitian melalui pendiskripsian variabel secara statistik deskriptif. Analisis kuantitaif yang digunakan adalah Regresi Multinomial Logistik (Regresi Logistik Politomous.)

Regresi logistikmultinomial digunakan untukmengetahui faktor-faktoryang mempengaruhi peluang petani dalam melakukan adopsi inovasi kelembagaan usahatani tebu. Dalam penelitian ini digunakan 3 kategori yakni pilihan petani terhadap kelembagaan usahatani TR Mandiri, TR KSU dan TR Kemitraan.

Persamaan regresi multinomial dengan tiga kategori pada variabel dependen mengikuti formulasi sbb (Hozmer,et al,1989) :

$$
\begin{aligned}
g_{1}(x) & =1 n\left[\frac{p(Y=1 \mid x)}{p(Y=0 \mid x)}\right] \\
& =b_{0}+b_{1} x_{1}+b_{1} x_{2}+\ldots+b_{1 p} x_{p} \\
& =\left(1, x^{\prime}\right) b_{1} \\
g_{2}(x) & =1 n\left[\frac{p(Y=2 \mid x)}{p(Y=0 \mid x)}\right] \\
& =b_{0}+b_{2} x_{1}+b_{2} x_{2}+\ldots+b_{2 p} x_{p} \\
& =\left(1, x^{\prime}\right) \mathbf{b}_{2}
\end{aligned}
$$

Bentuk operasional persamaan regresi logistik multinomial adalah:

(1) Pilihan Petani Bergabung dengan kelembagaan usahatani TR KSU

$$
g_{1}=\beta o+\beta_{1} L H N+\beta_{2} \text { BT }+\beta_{3} \text { RND }+\beta_{4} \text { PLM }+\beta_{5} \text { DIK }+ \text { ei }
$$

(2) Pilihan petani bergabung dengan kelembagaan usahatani TR Kemitraan

$$
g_{2}=\beta o+\beta_{1} L H N+\beta_{2} B T+\beta_{3} \text { RND }+\beta_{4} \text { PLM }+\beta_{5} \text { DIK }+ \text { ei }
$$

Keterangan :

$\mathrm{g}_{\mathrm{i}}$ : pilihan petani terhadap jenis lembaga usaha tani tebu

1 : kelembagaan tebu rakyat kerjasama usaha (TR KSU)

2 : kelembagaan tebu rakyat kemitraan (TR Kemitraan)

3 : kelembagaan tebu rakyat mandiri (TR Mandiri)

LHN : luas lahan petani yang ditanami tebu (ha)

RND : hasil rendemen sebagai proksi kualitas tebu yang diinginkan responden (\%)

PLM : pengalaman responden mengelola usahatani tebu (th) 
DIK : pendidikan responden (th)

BGAB: Biaya menjalankan usahatani tebu yang merupakan penjumlahan biaya transaksi dan biaya produksi (rp)

ßo : intercept

$\beta_{1} \ldots \beta_{5}$ Koefisien persamaan regresi logistik

$e_{i} \quad$ faktor pengganggu

Pengolahan data dengan program SPSS / Statistical Package for the Social Sciences yang saat ini diartikan Statistical Package for the Social Sciences (Triton,2006:3). Pilihan petani terhadap jenis lembaga usahatani tebu, sebagai basis rujukan adalah kelembagaan usahatani TR Mandiri. Kelayakan dan tidaknya model regresi logistik multinomial sebagai penduga pengaruh variabel independen terhadap variabel dependen dilakukan berbagai pengujian (Gozali, 2005:78).

\section{HASIL PENELITIAN}

\section{Deskripsi Variabel Model Logistik Politonomous}

Model regresi logistik politonomous merupakan pengembangan model Ipogistik dalam variable dependennya. Dalam model logistik sederhana, variabel dependen merupakan variabel biner yang hanya terdiri dari 2 pilihan, sementara dalam regresi logistik politonomous variabel dependen yang digunakan terdiri lebih dari 2 pilihan. Permasalahan tersebut sebetulnya dapat dipecahkan dengan analisis diskriminan dengan syarat dipenuhi asumsi multivariate yang berdistribusi normal. Sementara dalam analsis regresi logistik tidak perlu asumsi normalitas data pada variabel bebasnya karena merupakan campuran antara variabel kontinyu (metrik) dan kategorikal (non-metrik) (Hosmer:1989:216, Ghozali:2006:71)

Variabel dependen $\mathrm{G}$ merupakan piihan petani dalam menjalankan usahatani tebu yang ada yakni model kelembagaan tebu rakyat kerjasama usaha (TRKSU) dan model kelembagaan tebu rakyat kemitraan (TR Kemitraan) pada satu sisi dan petani tidak memilih bergabung dengan inovasi kelembagaan yang dilakukan oleh PG Madukismo yakni dengan menjalanakan usahatani secara mandiri (TR Mandiri) pada sisi lain. Dengan demikian variabel dependen (g) terdiri dari 3 jenis pilihan petani dalam menjalankan usahatani tebu yaitu: :

1. jenis kelembagaan usahatani tebu rakyat kerjasama usaha (TRKSU)

2. jenis kelembagaan usahatani tebu rakyat kemitraan (TR Kemitraan)

3 : jenis kelembagaan usahatani tebu rakyat mandiri (TR Mandiri)

Adapun variabel independen yang mempengaruhi peluang petani dalam menentukan pilihan jenis kelembagaan usahatani meliputi:

1. LHN : luas lahan petani yang ditanami tebu (ha)

2. RND : hasil rendemen sebagai proksi kualitas tebu yang diinginkan petani (\%)

3. PLM : pengalaman petani mengelola usahatani tebu (th)

4. DIK : pendidikan petani (th)

5. BGAB: Biaya menjalankan usahatani tebu/penjumlahan biaya transaksi dan biaya produksi (rp)

Distribusi frekusensi variabel dependen dan variabel-variabel independen atas sampel sebanyak 133 responden disajikan tabel berikut: 
Pelaksanaan Usahatani Tebu Pasca Pencabutan Inpres....; Unggul Priyadi

Tabel 5.5: Distribusi Frekuensi Statistik Variabel Regresi Logistik Multinolial

\begin{tabular}{|c|c|c|c|c|c|c|c|}
\hline & $G$ & $L H N$ & $R N D$ & $P L M$ & DIK & $B G A B$ \\
\hline$N$ & Valid & 133 & 133 & 133 & 133 & 133 & 133 \\
\hline & Missing & 0 & 0 & 0 & 0 & 0 & 0 \\
\hline & & 2.4060 & 1.1026 & 6.4408 & 11.1128 & 10.9925 & 9901932.2707 \\
\hline & Error of Mean & .05446 & .03234 & .01924 & .58223 & .20237 & 302470.99091 \\
\hline & dian & 2.0000 & 1.0000 & 6.4000 & 9.0000 & 12.0000 & 8803920.000 \\
\hline & & 3.00 & 1.00 & 6.70 & 7.00 & 12.00 & 4426960.00 \\
\hline & Deviation & .62810 & .37291 & .22194 & 6.71459 & 2.33386 & 3488265.63579 \\
\hline & iance & .395 & .139 & .049 & 45.086 & 5.447 & 12167997145813 \\
\hline & whess & -.569 & .560 & .051 & .955 & -169 & .553 \\
\hline & $\begin{array}{l}\text { Error of } \\
\text { wness }\end{array}$ & .210 & .210 & .210 & 210 & .210 & .210 \\
\hline & & 2.00 & 1.70 & .74 & 31.00 & 11.00 & 15017784.00 \\
\hline & imum & 1.00 & .30 & 6.10 & 1.00 & 6.00 & 2914256.00 \\
\hline & хітит & 3.00 & 2.00 & 6.84 & 32.00 & 17.00 & 17932040.00 \\
\hline $\mathrm{Su}$ & & 320.00 & 146.65 & 856.62 & 1478.00 & 1462.00 & 1316956992. \\
\hline
\end{tabular}

a Calculated from grouped data.b Multiple modes exist. The smallest value is shown

Berdasarkan tabel distribusi frekuensi di atas dapat dijelaskan bahwa:

1. Jumlah responden $(\mathrm{N})$ yang merupakan sampel sebanyak 133 petani tebu dan jumlah data tersebut valid (sah diproses). Missing $=0$ menunjukkan bahwa tidak ada yang hilang data sehingga tidak ada data yang belum terproses 0 .

2. Mean untuk variabel g yang masing-masing merupakan dumi maka nilai mean tidak ada arti statistiknya, karena besaran variabel dumi nilainya hanya merupakan pembeda yang merupakan nilai dari variabel pilah. Nilai mean dikaitkan dengan mode dan median variabelvariabel tersebut dapat digunakan untuk mendeteksi normalitas sebaran distribusi data. Jika nilai besaran rata-rata hitung $=$ median $=$ modus maka akan diperoleh suatu distribusi sebaran data yang simetris dan sebaliknya jika sebaran distribusi data tidak simetris maka nilai: mean $\neq$ median $\neq$ modus. Besaran nilai hitung dipengaruhi oleh nilai ekstrim sementara modus tidak dipengaruhi nilai ekstrim dan median dipengaruhi oleh kedudukannya (Dayan:2000, Kustituanto:1994).

Mean variabel lain yang mempunyai arti secara statistik adalah:

a. Iuas lahan petani yang ditanami tebu $L H N=1,1026$ yang berarti rata-rata luas lahan petani yang ditanami tebu pada musim tanam (MT) tahun 2006 atau musim giling (MG) tahun 2007 adalah 1,1026 hektar. Standar Error of Mean digunakan untuk memperkirakan besar rata-rata populasi berdasarkan jumlah sampel, yakni sebesar Mean \pm 2 Standard Error of Mean. Pada standar error of mean dan tingkat kepercayaan $95 \%(\alpha=5 \%)$, maka rata-rata populasi luas lahan petani yang ditanami tebu diperkirakan: 1,1026 $\pm(2$ $.0,03234)=1,1026 \pm 0,06468$, atau antara 1,038 - 1,167 hektar.

b. Rendemen sebagai proksi kualitas tebu yang diharapkan petani, RND: 6,4408, berarti rendemen yang dihasilkan pada MG tahun 2007 adalah 6,4408 persen. Dengan nilai standard error of mean 0,1924 dan tingkat kepercayaan $95 \%(\alpha=5 \%)$, maka ratarata rendemen diperkirakan: $6,4408 \pm(2.0,1924)=6,4408 \pm 0,3848$, atau antara 6,056 - 6,8256 persen

c. Pengalaman petani menjalankan usahatani tebu, PLM: 11,1128 tahun, berarti rata-rata pengalaman petani menjalankan usahatani tebu pada MG tahun 2007 adalah 11,11 tahun. Dengan nilai standard error of mean 0,58223 dan tingkat kepercayaan $95 \%$, $(\alpha=5 \%)$ maka rata-rata populasi pengalaman petani menjalankan usahatani tebu diperkirakan antara 9,9483-12,28 tahun. 
d. Pendidikan petani DIK 10,9925 tahun, berarti rata-rata pendidkan petani tebu pada MG tahun 2007 adalah 10,9925 tahun. Dengan nilai standard error of mean 0,20237 dan tingkat kepercayaan $95 \% \quad(\alpha=5 \%)$, maka rata-rata populasi pendidikan petani diperkirakan antara 10,59 - 11,5 tahun. Hal ini berarti rata-rata populasi pendidikan petani adalah SMTA.

e. Biaya menjalankan usahatani tebu, BGAB Rp 9.901.923,27 berarti rata-rata biaya menjalankan usahatani tebu pada MG tahun 2007 adalah Rp 9.901.923,27. Dengan nilai standard error of mean 302.470,99 dan tingkat kepercayaan $95 \%$ ( $\alpha=5 \%$ ), maka rata-rata populasi biaya menjalankan usahatani tebu diperkirakan antara 9.296.981 - Rp 10.506.865,25

3. Range digunakan untuk menentukakan jarak suatu distribusi frekuensi yang menunjukkan jarak nilai terbesar dan nilai terkecil yang terdapat dalam sebuah distribusi. Namun demikian pengukuran dengan menggunakan range merupakan pengukuran jarak suatu dispersi yang paling sederhana. Untuk variabel g yang merupakan dumi maka nilai range tidak ada arti statistiknya, karena besaran variabel dumi nilainya hanya merupakan pembeda yang merupakan nilai dari variabel pilah. Ada pun niali range dari variabel-variabel lain yang mempunyai arti secara statistik adalah sebagai berikut:

a. range luas lahan petani yang ditanami tebu LHN adalah 1,7 hektar dengan lahan paling sempit 0,3 hektar dan paling luas 2 hektar. Hal ini menunjukkan terdapat perbedaan penguasaan lahan usahatani tebu yang timpang di tingkat petani tebu.

b. range hasil rendemen dari tebu yang digiling RND adalah 0,74 persen dengan hasil minimum 6,1 persen dan nilai maksimum 6,84 persen. Hal ini berarti perbedaan hasil rendemen tebu yang digiling antara petani sampel pada musim tanam (MT) tahun 2006 atau musim giling (MG) tahun 2007 cukup besar. Dengan demikian, faktor-faktor yang mempengaruhi perolehan rendemen baik di tingkat usahatani tebu maupun di luar usahtani tebu seperti penebangan tebu, pengangkutan tebu serta proses penggilingan tebu di PG Maduksimo, perlu mendapatkan perhatian yang serius.. Pihak PG Maduksimo dapat melakukan efisiensi mulai dari proses penimbangan tebu, pengengkutan tebu di pabrik sampai pada proses penggilingan tebu. Untuk peran PG Maduksimo di tingkat usahatani dapat memberikan kontribusi mulai bantuan alat-alat pengolahan lahan, pengadaan bibit, cara perawatan tanaman serta pebgaturan manajemen tebang dan pengangkutan tebu

c. range pengalaman petani menjalankan usahatani tebu DIK adalah 31 tahun, dengan pengalaman paling sedikit 1 tahun dan paling banyak 32 tahun. Hal ini berarti terdapat perbedaan pengalaman petani mengelola usahatani tebu petani sampel pada MG tahun 2007 yang sangat timpang. Keadaaan ini mengindikasikan terjadinya petani yang tetap bertahan menjalankan usahatani tebu dan masuknya petani tebu baru.

d. range pendidikan petani adalah 11 tahun yang menunjukkan perbedaan pendidikan terendah 6 tahun dan teritnggi 17 tahun. Hal ini menunjukkan kesenjangan pendidikan para petani tebu sangat bervariasi dan sangat dimungkinkan terjadinya perbedaan kemampuan pengelolaan pelaksanaan usahatani tebu secara teknis agronomis dan kemampuan manajerial pengelolaan input, pengadaaan sarana produksi serta pengelolaan manajemen tebang angkut

e. range biaya menjalankan usahtani tebu adalah $\mathrm{Rp}$ 15.011.115 dengan biaya menjalankan paling rendah $\mathrm{Rp}$ 2.914.256 dan biaya paling tinggi Rp 17.932.040. Perbedaan biaya menjalankan usahatani tebu yang teridir dari biaya produksi dan biaya transaksi, berkaitan dengan luaan lahan usahatani tebu petani sampel pada MG tahun 2007 yang sangat bervariatif. 


\section{Regresi Logistik Multinomial (Regresi logistik Politonomous)}

Dalam menyusun model persamaan regresi logistik multinomial atas keputusan petani memilih jenis lembaga usahatani tebu yang di dalamnya terdapat tiga pilihan yaitu TR KSU diberi kode 1, TR Kemitraan diberi kode 2, dan TR Mandiri diberi kode 3. Ketiga kategori dipilih salah satu sebagai kategori referensi untuk pembanding dalam analisis. Dalam hal ini dipilih strategi TR Mandiri sebagai kategori referensi. Dalam penelitian ini maka terdapaat ada dua persamaan untuk kategori TR KSU dan TR Kemitraan.

Melalui penentuan salah satu sebagai kategori referensi maka di dalam analisis dapat digunakan untuk membandingkan pilihan lembaga usahatani tebu TR KSU dengan TR Kemitraan dengan menempatkan TR Mandiri sebagai pembanding atas pengaruh variabel independen. Ada pun variabel independen adalah luas lahan yang ditanamai tebu (LHN), biaya transaksi (RND), rendemen (PLM), pengalaman mengelola usahatani tebu (DIK),

Pada taraf nyata a 5 persen, semua variabel independen dan intercept (LHN, RND, PLM, DIK, BGAB) memberikan kontribusi pada model logistik multinomial. Untuk mengamati pengaruh peluang dari masing-masing variabel bebas disajikan pada tabel estimasi parameter berikut:

Tabel 3: Estimasi Parameter

\begin{tabular}{|c|c|c|c|c|c|c|c|c|c|}
\hline \multirow[t]{2}{*}{$G(a)$} & & \multirow[t]{2}{*}{$B$} & \multirow[t]{2}{*}{$\begin{array}{l}\text { Std. } \\
\text { Error }\end{array}$} & \multirow[t]{2}{*}{ Wald } & \multirow[t]{2}{*}{$d f$} & \multirow[t]{2}{*}{ Sig. } & \multirow[t]{2}{*}{$\operatorname{Exp}(B)$} & \multicolumn{2}{|c|}{$\begin{array}{l}\text { 95\% Confidence Interval } \\
\text { for } \operatorname{Exp}(B)\end{array}$} \\
\hline & & & & & & & & $\begin{array}{l}\text { Lower } \\
\text { Bound }\end{array}$ & Upper Bound \\
\hline \multirow[t]{6}{*}{1.00} & Intercept & -61.529 & 38.372 & 2.571 & 1 & .109 & & & \\
\hline & $L H N$ & -24.856 & 10.781 & 5.316 & 1 & .021 & $1.60 E-011$ & $\begin{array}{r}1.07 \mathrm{E}- \\
02\end{array}$ & .024 \\
\hline & $R N D$ & 12.122 & 6.103 & 3.944 & 1 & .047 & 183783.024 & 1.173 & 28806800761.8 \\
\hline & PLM & -.814 & .401 & 4.129 & 1 & .042 & .443 & 202 & .972 \\
\hline & $D I K$ & -.637 & 393 & 2.631 & 1 & 105 & .529 & 245 & 1.142 \\
\hline & $B G A B$ & .000 & .000 & 4.824 & 1 & .028 & 1.000 & 1.000 & 1.000 \\
\hline \multirow[t]{6}{*}{2.00} & Intercept & 12.993 & 9.346 & 1.933 & 1 & 164 & & & \\
\hline & LHN & 6.499 & 3.745 & 3.011 & 1 & .083 & 664.513 & 431 & 1024620.797 \\
\hline & $R N D$ & 177 & 1.509 & .014 & 1 & .907 & 1.193 & .062 & 22.981 \\
\hline & PLM & -.292 & .064 & 20.43 & 1 & .000 & .747 & .658 & .848 \\
\hline & DIK & -.825 & .217 & 14.49 & 1 & .000 & .438 & .286 & .670 \\
\hline & $B G A B$ & .000 & .000 & 4.476 & 1 & .034 & 1.000 & 1.000 & 1.000 \\
\hline
\end{tabular}

a The reference category is: 3.00 .

Berdasarkan besaran koefisien pengaruh masing-masing nilai-nilai koefisien variabel independen dan tingkat signifikansinya dapat disusun persaman regresi logistik multinomial untuk pilihan terhadap TR KSU dan TR Kemitraan dibandingkan piliihan TR Mandiri adalah sebagai berikut:

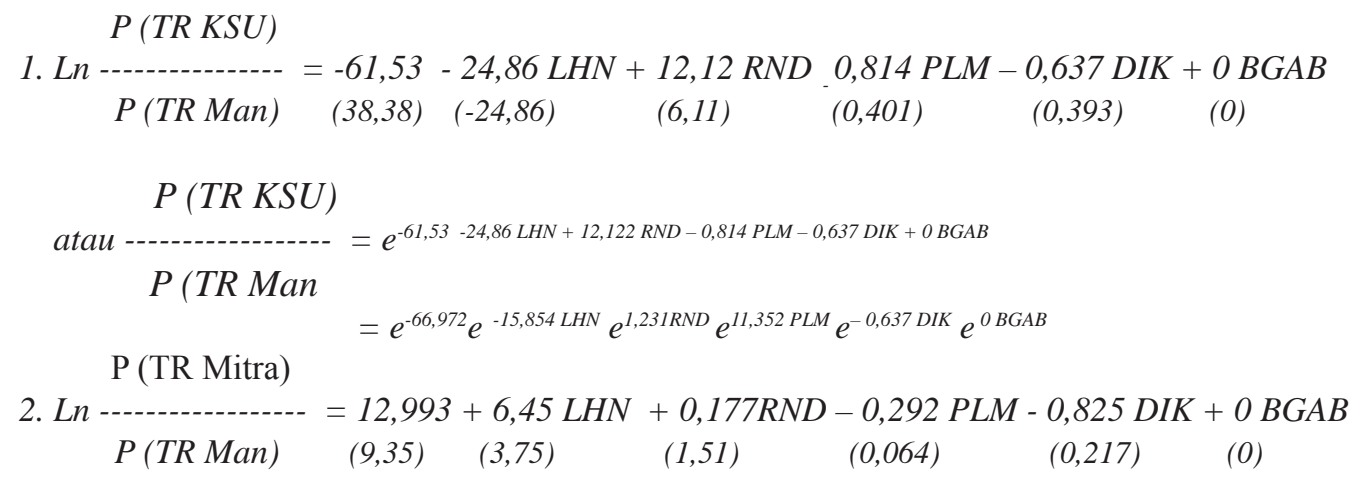




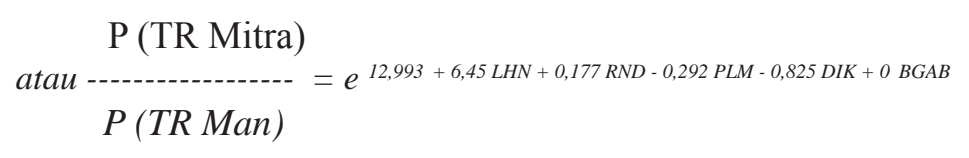

$=e^{12,993} e^{6,45 L H N} e^{0,177 R N D} e^{-0,292 \text { PLM }} e^{-0,825 \text { DIK }} e^{0 \text { BGAB }}$

Pada kedua persamaan di atas, bila semua variabel independen dimasukkan nilai 0 yang menunjukkan minat awal dari para petani untuk memilih jenis kelembagaan usahtani tebu maka akan didapat nilai persamaan:

1. Untuk pilihan kelembagaan TR KSU daripada TR Mandiri

Ln (P TR KSU) / (P TR Mandiri) $=-61,53$

$\left(P\right.$ TR KSU) / $(P$ TR Mandiri $)=\mathrm{e}^{-61,53}=1,9\left(10^{-27}\right)$

$(\mathrm{P}$ TR KSU $)=1,9\left(10^{-27}\right) \quad(\mathrm{P}$ TR Mandiri $)$

Hal tersebut berarti peluang minat awal para petani tebu untuk menentukan pilihan kelembagaan usahatani TR KSU adalah 1,9 (10-27) kali dibandingkan menjalankan usahtani TR Mandiri. Dengan demikian peluang petani menjalankan usahatani TR Mandiri lebih besar dibandingkan menentukan pilihan kelembagaan usahatani TR KSU

2. Untuk pilihan kelembagaan TR Kemitraan daripada TR Mandiri

Ln (P TR Mitra) / (P TR Mandiri $)=12,993$

$($ P TR Mitra) / (P TR Mandiri $)=\mathrm{e}^{12,993}=43.011,31$

$(\mathrm{P}$ TR Mitra $)=43.011,31(\mathrm{P}$ TR Mandiri)

Hal tersebut berarti peluang minat awal para petani untuk menentukan pilihan kelembagaan memilih usahatani TR Kemitraan adalah 43.011,31 kali menjalankan usahtani TR Mandiri. Dengan demikian peluang petani lebih besar menjalankan usahatani TR kemitraan dibandingkan dengan menentukan pilihan kelembagaan usahatani TR Mandiri. Berdasarkan ilustrasi kedua persamaan tersebut mengindikasikan minat awal para petani untuk melakukan adopsi inovasi kelembagaan usahtani tebu lebih mengutamakan pilihan pada TR Kemitraan diikuti TR Mandiri dan pilihan terakhir pada TR KSU.

Berdasarkan tingkat signifikansi masing-masing variabel (pada taraf nyata a 5 persen) hanya variabel rendemen yang secara individu tidak berpengaruh terhadap peluang petani dalam menentukan pilihan melakukan adopsi inovasi kelembagaan usahatani TR Kemitraan. Hal ini berarti, peluang petani dalam melakukan adopsi inovasi kelembagaan TR kemitraan secara parsial dipengaruhi oleh variabel luas lahan, pengalaman menjalankan usahtani tebu, pendidikan dan biaya menjalankan usahatani tebu (biaya transaksi dan biya produksi).

Ilustrasi besarnya peluang pengambilan keputusan petani dalam menentukan jenis kelembagaan usahatani tebu dilakukan dengan mengambil besaran nilai-nilai variabel luas lahan, biaya transaksi, rendemen, pengamalan menjalankan usahatani tebu dan pendidikan responden ke dalam persamaan multinomial logit. Besaran nilai masing-masing variabelvariabel independen tersebut dengan mengambil nilai tertinggi, rata-rata dan terendah. Peluang pengambilan keputusan petani dalam menentukan jenis kelembagaan usahatani tebu TR KSU daripada TR Mandiri serta TR Kemitraan daripada TR Mandiri masing-masing ditunjukkan pada Tabel 4. 
Pelaksanaan Usahatani Tebu Pasca Pencabutan Inpres....; Unggul Priyadi

Tabel 4: Perhitungan Peluang Menentukan Pilihan Kelembagaan Usahatani TR KSU dibandingkan dengan TR Mandiri

\begin{tabular}{|l|l|c|c|c|}
\hline No & Variabel & Nilai Tertinggi & Nilai Rata-Rata & Nilai Terendah \\
\hline 1. & LHN (ha) & 2 & 1,103 & 0,3 \\
\hline 2. & RND (\%) & 6,84 & 6,441 & 6,1 \\
\hline 3. & PLM (th) & 32 & 11,113 & 1 \\
\hline 4. & DIK (th) & 17 & 11 & 6 \\
\hline 5 & BGAB (Rp) & 17.932 .040 & 9.901 .932 & 2.914 .256 \\
\hline Nilai g(ln) & $-65,227$ & $-26,137$ & 0,31 \\
\hline \multicolumn{2}{|l}{ Nilai g (peluang) } & $(<0,5)$ & $(<0,5)$ & 1,36 \\
\hline \multicolumn{2}{|l}{ Kriteria besaran $g$} & Tdk terdapat peluang & Tdk terdapat peluang & terdapat peluang \\
\hline
\end{tabular}

Sumber: Data primer, diolah

Berdasarkan ilustrasi pada berbabagai nilai variabel independen menunjukkan bahwa pada nilai-nilai tertinggi dan nilai rata-rata pada variabel independen tidak akan terjadi peluang petani melakukan adopsi inovasi dengan memilih menjalankan usahatani tebu melalui kelembagaan TR KSU daripada TR Mandiri. Sebaliknya pada nilai terendah variabel independen adakn terjadi peluang melaksanakan usahatani TR KSU daripada TR Mandiri.

Hal berbeda dalam peluang petani menjalankan usahatani TR Kemitraan dibandingkan TR Mandiri. Pada berbagai nilai ilustrasi variabel independen menunjukkan akan terjadi peluang menjalankan usahatani melalui kelembagaan TR Kemitraan daripada TR Mandiri (tabel 5).

Tabel 5: Perhitungan Peluang Menentukan Pilihan Kelembagaan Usahatani TR Kemitraan dibandingkan dengan TR Mandiri

\begin{tabular}{|l|l|c|c|c|}
\hline No & Variabel & Nilai Tertinggi & Nilai Rata-Rata & Nilai Terendah \\
\hline 1. & LHN $(\mathrm{ha})$ & 2 & 1,103 & 0,3 \\
\hline 2 & B T $(\mathrm{Rp})$ & 1.541 .040 & $701.751,8$ & 267,75 \\
\hline 3 & RND $(\%)$ & 6,84 & 6,441 & 6,1 \\
\hline 4. & PLM (th) & 32 & 11,113 & 6 \\
\hline 5 & DIK (th) & 17 & 11 & 28,18 \\
\hline Nilai g (ln) & 14,63 & 8,928 & $>0,5$ \\
\hline \multicolumn{2}{|l|}{ Nilai g (peluang) } & $>0,5$ & $>0,5$ & terdapat peluang \\
\hline \multicolumn{2}{|l}{ Kriteria $g$} & Terdapat peluang & terdapat peluang & . \\
\hline
\end{tabular}

Sumber: Data primer, diolah

Variabel rendemen yang tidak signifikan mempengaruhi petani dalam melakukan adopsi inovasi kelembagaan usahatani TR Kemitraan serta perhitungan peluang melalui ilustrasi berbagai besaran variabel-variabel independen dalam dilakukan pemaparan sebagai berikut:

\section{Pilihan Jenis Kelembagaan Usahatani Tebu}

Responden dalam menjalankan usahatani tebu lebih banyak memilih jenis kelembagaan usahatani TR Mandiri yang berarti tidak bergabung dengan inovasi kelembagaan PG Madukismo. Dengan demikian, para petani dalam menjalankan usahatani tebu secara teknis agronomis dan pendanaan tidak sepenuhnya bergantung dengan pihak lain termasuk PG Madukismo. Di samping itu para petani tenu TR Mandiri tidak memperoleh jaminan pendapatan minimum (JPM) yang diberikan PG Madukismo. Sebagai konsekuensinya, apabila dalam menjalankan usahatani mengalami kegagalan panen akan menghadapi resiko tidak memperoleh pendapatan. Selaras dengan hal ini (Sutanto, 2003), menyatakan dalam menjalankan usahatani dihadapkan pada ketidakpastian yang dapat berupa: resiko alamiah, fluktuasi pasar, ketidakpastian sosial dan kebijakan pemerintah.

Resiko alamiah yang berupa dampak yang tidak dapat diduga dari iklim; hama, penyakit dan bencana lainnya. Fluktuasi Pasar berkaitan ketidakpastian harga pasar pada saat menjual hasil produksi membeli faktor produksi serta kelangkaan informasi akibat ketidaksempurnaan pasar. Ketidakpastian sosial merujuk pada perbedaan kontrol petani atas sumber daya dan ketergantungan hidup sekelompok petani kepada kelompok lain (dalam hal ini pemilik tanah dan faktor produksi melalui sistem bagi hasil). 
Kebijakan pemerintah berkaitan kebijakan ekonomi dan non ekonomi dalam rangka merespon situasi domestik dan luar negri yang berdampak langsung maupun tidak langsung pada pelaksanaan usahatani. Kebijakan penyesuaian harga luar negeri, kelangkaan produk yang dibutuhkan pada pasar domestik dapat menimbulkan gejolak harga barang-barang pertanian.

Dikaitkan dengan sikap seseorang dalam menghadapi suatu persoalan yang mengandung resiko dapat dibedakan menjadi tiga,yaitu: sikap menghindari resiko, netral atau penggemar resiko (Mangkusubroto, 1992). Sikap menghindar resiko bila seseorang menetapkan nilai ekivalen tetap suatu kejadian tak pasti lebih rendah dari nilai ekspektasi kejadian tersebut. Sikap netral terhadap resiko bila seseorsng menyatakan ekivalen tetap suatau kejadian sama dengan nilai ekspektasinya, sedangkan sikap penggemar resiko jika seseorang menetapkan ekivalen tetap atas suatu kejadian tak pasti lebih besar daripada nilai ekspektasi dari kejadian tersebut.

Perbedaan antara nilai ekspektasi suatu peristiwa dengan ekivalen tetap disebut sebagai risk premium (nilai ekspektasi - ekivalen tetap). Premi resiko diartikan sebagai sejumlah uang (besaran lain) yang rela dilepaskan seseorang untuk menghindarkan resiko yang terlihat pada kejadian tak pasti. Jika petani sebagai penghindar resiko maka premi resikonya selalu positip. Semakin besar premi resiko, maka penghindar resiko akan makin besar (Mangkusubroto, 1992).

Berkaitan petani dalam memilih berbagai alternatif tindakan, beberapa kriteria pemilihan perlu ditetapkan terlebih dahulu. Hal ini dipakai sebagai dasar pembanding kemungkinan konsekuensi yang terjadi dari suatu tindakan yang dilakukan. Kriteria pemilihan yang tepat adalah kepuasan yang diharapkan dan tindakan paling baik yang dipilih adalah memaksimumkan kepuasan yang diharapkan oleh pembuat keputusan (Anderson dkk, 1984). Pada waktu bersamaan, persepsi individu tentang resiko pembuat keputusan secara implisit masuk dalam proses pemilihan tindakan.

Dalam hal pemilihan tindakan, petani sering dihadapkan pada keterbatasan penguasaan terhadap iklim, pasar tempat membeli factor produksi dan menjual produk serta lingkungan institusi tempat berusahatani, maka senantiasa dihadapkan pada masalah ketidakpastian terhadap besarnya pendapatan usahatani yang diperoleh. Pada petani kecil, khususnya petani subsisten, faktor ketidakpastian merupakan suatu hal yang berpengaruh dan berperan besar dalam proses pengambilan keputusan (Sutanto dkk, 2003).

\section{Luas Lahan Petani yang Ditanami Tebu}

Variabel LHN secara individu berpengaruh pada peluang petani dalam menentukan pilihan petani melakukan adopsi inovasi kelembagaan usahatani yang dilakukan PG Maduksimo. Hal ini menunjukkan bahwa insentif JPM dari PG Madukismo kepada petani mampu menjadikan daya tarik untuk mengadopsi inovasi kelembagaan. Secara statistik, signifikansinya variabel tersebut sebagai akibat perbedaan yang sangat kecil antara batas bawah dan batas atas dari interval keyakinan $\operatorname{Exp}(B)$. Secara empirik petani dihadapkan pada rasionalitas terbatas dalam menentukan pilihan alternatif penggunaan lahan serta terbatasnya akses informasi pasar atas keutungan yang akan diperoleh dari berbagai kemungkinan jenis komoditas yang diusahakan.

Pada ilustrasi perhitungan peluang pilihan kelembagaan dengan memasukan berbagai nilai variabel-variabel independen yakni nilai terbesar, nilai rata-rata serta nilai terendah pada pemilihan TR KSU daripada TR Mandiri dan pilihan TR Kemitraan daripada TR Mandiri menunjukkan variabel luas lahan berpengaruh secara positip. Hal ini berarti semakin luas lahan petani sebagai pelaku dalam sistem agribisnis berupaya untuk mentransfer risiko dan mengurangi dampak suatu resiko terhadap kelangsungan usahanya. Pada prisnsipnya petani melakukan pengalihan resiko produksi secara fisik dan kemungkinan merosotnya volume 
produksi yang mungkin disebabkan oleh bencana alam, serangan hama dan penyakit tanaman, kebakaran, dan karena faktor-faktor lainnya (Said dkk, 2001).

Dalam hal tidak terdapat asuransi pertanian, menurut Duft (1979) (dalam Said, 2001:114) bahwa diversifikasi merupakan salah satu cara untuk mengeliminasi dampak negatif atau risiko yang dihadapi pengusaha agribisnis. Agribisnis pada dasarnya bergerak pada beberapa lini usaha yang memiliki risiko yang berbeda memungkinkan kerugian yang diderita peyani pada suatu lini produk tertentu dapat ditutupi dengan keuntungan pada lini produk lainnya. Melalui diversifikasi berarti tampil dalam berbagai jenis bentuk. Melakukan diversifikasi juga berarti bergerak pada beberapa lini produk. Namun, diversifikasi menjadi tidak populer karena meningkatnya tekanan efisiensi, sehingga spesialisasi pada suatu lini produk, yang memiliki keunggulan komparatif dan keunggulan kompetitif, menjadi suatu pilihan.

Dishutbun Propinsi DIY 2006 melakukan kajian bahwa faktor-faktor yang menjadi hambatan dalam pengembangan tanaman perkebunan adalah keterbatasan lahan pertanian, pengetahuan dan keterampilan petani, permodalan, akses produksi dan pemasaran. Pendekatan pengembangan perkebunan yang dilaksanakan selama ini merupakan kegiatan lanjutan dan program sebelumnya dengan penekanan pada pemberdayaan petani dan kelembagaan petani agar semakin produktif (Dishutbun DIY, 2006)

Pengembangan tanaman tebu pada setiap wilayah kabupaten di Propinsi DIY selaras dengan pengembangan komoditas andalan dan komoditas unggulan. Komoditas andalan merupakan pilihan komoditas yang cocok dikembangkan di suatu kawasan sesuai dengan teknik budidaya dan dapat diterima petani karena bisa mendukung kehidupannya tetapi tidak tergantung pada keluasannya. Untuk pengembangan komoditas unggulan merupakan pilihan komoditas yang dikembangkan dan dikelola oleh kelompok dalam kawasan tertentu dengan skala ekonomi tertentu, minimal 50 ha. Potensi pengembangan usahatani tebu dapat dikelola dengan baik apabila telah dikaji berdasarkan skala prioritas maupun kesesuaian lahan untuk wilayah pengembangannya pada setiap kabupaten dengan mengkaji skala prioritas pengembangan (Dishutbun, 2006)

Dinas Kehutanan dan Perkebunan Propinsi DIY menyusun strategi pembangunan perkebunan, dengan memperhatikan faktor terpeting untuk menjalankan usahatani yaitu kesesuaian lahan. Tanaman dapat tumbuh secara optimal apabila terpenuhi persayaratan teknis agronomis yang secara umum dapat dibagi menjadi beberapa komponen, yakni: suhu, CH, kelembaban nisbi dan sifat tanah (Marwan dkk, 1997; Bunting, 1981).

\section{Hasil Rendemen (\%)}

Variabel RND secara individu berpengaruh positip dan signifikan terhadap keputusan petani menentukan pilihan kelembagaan usahatani TR KSU dibandingkan TR Mandiri dan pilihan kelembagaan usahatani TR Kemitraan dibandingkan TR Mandiri. Pengaruh positip terhadap pilihan petani dalam adopsi inovasi kelembagaan selaras dengan rasionalitas terbatas dalam pengambilan keputusan. Simon, (1961) menyatakan bahwa orang berniat membuat keputusan, kapasitas mengevaluasi secara akurat seluruh kemungkinan alternatif keputusan secara fisik terbatas (Douma, et al, 1992).

\section{Pengalaman Petani Mengelola Usahatani Tebu dan Pendidikan Petani}

Secara individu tidak signifikannnya variabel PLM dan DIK tidak sesuai dengan hipotesis dan teori yang secara umum berlaku. Sinungan, (1992) menyatakan latar belakang pendidikan, dan pengalaman seseorang sangat berpotensi meningkatkan keahlian yang dimiliki untuk memilih jenis usaha. Pengalaman kerja dan pendidikan mempunyai peranan dalam meningkatkan ketrampilan kerja yang akhirnya mampu meningkatkan produktivitas. Soekartawi 
(2005) menyatakan bahwa pengalaman dan pendidikan sangat mendukung petani dalam melakukan adopsi inovasi.

Pengalaman menjalankan usahatani tebu dan pendidikan petani dalam menentukan pilihan kelembagaan usahatani secara bersama-sama dengan variabel lain menunjukkan semakin berpengalaman petani dalam menjalanakan usahtani tebu dan pendidikan yang semakin tinggi menjadikan petani tidak melakukan adopsi inovasi kelembagaan melainkan lebih senang menjalankan usahtani TR Mandiri. Hal ini berbeda dengan faktor-faktor yang mempengaruhi adopsi inovasi (Soekartawi, 2005) yang menyatakan bahwa pendidikan dan pengalaman petani menjalankan usahatani merupakan faktor yang mempengaruhi adopsi inovasi. Semakin tinggi pendidikan dan pengalaman petani akan lebi mudah melakukan adopsi inovasi.

\section{Biaya Menjalankan Usahatani Tebu}

Variabel biaya menjalankan usahatani tebu yang terdiri dar biaya transaksi dan biaya produksi berpengaruh pada pilihan kelembagaan usahatani TR KSU daripada TR Mandiri serta TR Kemitraan daripada TR Mandiri. Hal ini menunjukkan bahwa petani sepenuhnya memahami secara mendalam bahwa biaya transaksi sebagai komponen biaya yang harus dipertimbangkan dalam menghasilkan produksi gula. Baik pada pilihan TR KSU dan TR Kemitraan variabel BT bersama variabel lain secara agregat berpengaruh secara positip. Hal ini berarti semakin besar biaya transaksi yang dikeluarkan, petani berupaya mentransfer risiko dan mengurangi dampak merugikan terhadap kelangsungan usahanya. Dalam hal ini petani berusaha menghindari resiko (Mangkusubroto,1992). Secara statistik signifikansinya variabel tersebut akibat batas bawah dan batas atas dari interval keyakinan $\operatorname{Exp}(B)$ nilainya sama.

\section{KESIMPULAN DAN REKOMENDASI KEBIJAKAN}

Berdasarkan analisis data peluang petani dalam menjalankan usahatani tebu setelah ditetapkannya Inpres No 5 Tahun 1998 yang merupakan konsekuensi pencabutan Inpres No. 5 Tahun 1997 tentang Program Pengembangan Tebu Rakyat (tindak lanjut Inpres No. 9/1975 tanggal 22 April 1975) diperoleh kesimpulan dan rekomendasi kebijakan terhadap pelaksanaan usahatani tebu di wilayah kerja PG Madukismo.

Peluang petani melaksanakan usahtani tebu dalam menentukan pilihan kelembagaan usahatani TR KSU dibandingkan TR Mandiri serta pilihan kelembagaan usahatani TR Kemitraan dibandingkan TR Mandiri secara bersama-sama dipengaruhi oleh luas lahan tebu, rendemen sebagai proksi kualitas hasil tebu, pengalaman responden menjalankan usahatani tebu, pendidikan petani dan biaya menjalankan usahatani tebu (biaya produksi dan biaya transaksi)

Secara parsial peluang petani melaksanakan usahtani tebu dalam menentukan pilihan kelembagaan usahatani TR KSU dibandingkan TR Mandiri dipengaruhi luas lahan tebu, rendemen, pengalaman responden menjalankan usahatani tebu, pendidikan petani dan biaya menjalankan usahatani tebu. Sementara dalam menentukan pilihan kelembagaan usahatani TR Kemitraan dibandingkan TR Mandiri dipengaruhi luas lahan tebu, pengalaman responden menjalankan usahatani tebu, pendidikan petani dan biaya menjalankan usahatani tebu sedangkan rendemen sebagai proksi kualitas hasil tebu tidak berpengaruh

Pasokan tebu dari luar wilayah Propinsi DIY pada MG tahun 2007 mempunyai peranan yang signifikan untuk keberlangsungan giling PG Madukismo yakni mencapai 60,28 persen, sedangkan sisanya 39,62 persen berasal dari wilayah Propinsi DIY. Pasokan tebu dari petani yang berasal dari luar wilayah Propinsi DIY didominasi TR Mandiri yang mencapai 90,39 persen dan sisanya TR Kemitraan sebanyak 9,61 persen. Untuk pasokan tebu dari wilayah Propinsi DIY didominasi TR Kemitraan yang mencapai 58,51 persen diikuti TR Mandiri 28,06 persen dan TR KSU yang hanya 13,43 persen. 
Ada pun rekomendasi kebijakan yang dapat dilakukan untuk mendorong petani di wilayah Propisni DIY menjalankan usahtani tebu, tidak cukup hanya memberi insentif kepada para pemilik lahan berupa jaminan pendapatan minimum (JPM) juga diperlukan dorongan semua pihak yang berkaitan dengan pengembangan usahatani tebu serta peningkatan intensitas pabrik gula Maduksimo dalam menjalin kerjasama denagn berbagai pihak dalam menyediakan areal usahatani tebu.

Besarnya pengaruh rendemen terhadap peluang petani menjalankan usahtani tebu sesuai pilihan kelembagaan yang ada maka sangat diperlukan upaya untuk meningkatkan besaran rendemen baik dari aspek manajemen penentuan maupun aspek pelaksanaan usahatani dan efisiensi pabrik gula Maduksimo yang sudah sangat tua. Manajemen penentuan rendemen yang diterapkan PG Maduksimo selama ini menggunakan penetapan rendemen kelompok, perlu mengkaji alternatif penetapan rendemen individu. Hal ini dimaksudkan agar dapat memacu petani untuk meningkatkan rendemen dari sisi pelaksanaan usahatani (on farm) serta menghilangkan kecurigaan para petani, meskipun saat ini dalam penetapan rendemen tengah memanfaatkan lembaga independen INSTIPER untuk menjembatani kepentingan petani dan PG Maduksimo.

Adanya keterbatasan dalam pelaksanaan penelitan maka pihak yang akan melakukan penelitian yang lebih mendalam perlu pengembangan dan pencermatan terhadap variabelvariabel independen sehingga model menjadi semakin baik serta mempertimbangkan penggunaan penelitian kualitatif.

\section{DAFTAR PUSTAKA}

-------, Badan Pusat Statistik. 2000. Statistik Impor

-------, Departemen Pertanian, Bahan Rakortas Perekonomian, Fokus: Revitalisasi Industri Gula Nasional, Jakarta, Desember 2002.

-------, P3GI dan Jurusan PPW FPS IPB, 1991. Peningkatan Efisiensi Pemasaran Tebu Lahan Kering di Jawa. Kerjasama P3GI dan PSW FPS IPB. Bogor.

--------, 1998. Penghentian pelaksanaan instruksi Nomor 5 tahun 1997 Tentang Program Pengembangan Tebu Rakyat, Inpresi. Jakarta

-------, 2001, Ditjen Bina Produksi Perkebunan. Pemikiran Untuk Akselerasi Peninmgkatan Produktivitas Gula Nasional.

-------, 2001, Ditjen Bina Produksi Perkebunan. Pemikiran Untuk Akselerasi Peninmgkatan Produktivitas Gula Nasional.

-------, 2002, Dirjen Bina Produksi Perkebunan.

--------, APTRI http: www.aptindonesia.com

--------, APTRI Publikasi wibe site http: www.aptindonesia.com

- ASA (American Sugar Alliance), 2000. World sugar price: Foreign subsidies distort global market. http:Ilwww.sugaralliance.com

Departemen Pertanian, Ringkasan Program Peningkatan Produktivitas Gula, Jakarta, September 2002. 
-------, Development Policy Review. Fiji And The Sugar Proticol: A Case for Trade-Based development Co-operation, USA. 16: 36-60.

-------, DGI, 2004. Dewan Gula Indonesia: Konsep Kebijakan Agribisnis Gula Nasional, Jakarta.

, DGI, 2005. Dewan Gula Indonesia: Konsep Kebijakan Pergulaan Nasional Terintegrasi, Jakarta.

-------, DGI, Informasi tentang Dewan Gula Indonesia, Dewan Gula Indonesia. Jakarta.

-------, DGI, Informasi Tentang Industri Gula dan Kebijaksanaannya. Jakarta.

-------, DGI, Informasi tentang kebijakan produksi, Dewan Gula Indonesia. Jakarta.

-------, DGI, Informasi tentang Kemitraan Petani dan Pabrik Gula, Dewan Gula Indonesia. Jakarta.

-------, DGI, Informasi tentang Ketentuan Impor Gula, Dewan Gula Indonesia. Jakarta.

-------, DGI, Informasi Tentang Penyediaan Modal Kerja, D G I. Jakarta.

-------, DGI, Informasi tentang Perdagangan Gula Antar Pulau, Dewan Gula Indonesia. Jakarta.

-------, DGI, Realitas Industri Gula di Indonesia, Dewan Gula Indonesia. Jakarta.

--------, Dinas Kehutanan dan Perkebunan. 2003. Program Akselerasi Peningkatan Produktivitas Gula DIY, Proyek Pengembangan Tebu D.I. Yogyakarta, .

-------, Dinas Kehutanan Perkebunan. 2004. laporan Pelakasanaan Proyek Pengembangan Tebu DIY Ta 2004 Dan Rencana Ta 2005, Yogyakarta.

-------, Dinas perkebunan. Makalah Kemitraan Yang Ideal Antara Petani Dengan Pabrik Gula, Dinas Perkebunan Propinsi Jawa Tengah

-------, Direktorat Jenderal Bina Produk Perkebunan, Departemen Pertanian, Tebu, Statist Perkebunan Indonesia, 2000-200. Jakarta November 2002.

-------, Direktorat Tanaman Semusim, Ditjen Bine Produksi Perkebunan "Hariar. Sugar Observer" tanggal 14 Jul: 2003, hal. 3)

-------, Kondisi Industri Gula di Jawa (Publikasi Pusat Penelitian Perkebunan Gula Indonesia, wibe site http/www.geocities.com/p3gi/isri/html)

--------, Kondisi Industri Gula di Jawa (Publikasi Pusat Penelitian Perkebunan Gula Indonesia, http: www.geocities.com/p3gi/isri/html

-------, PG madukismo. Prospek Agribisnis Tebu, Pemda Kab. Bantul Bekerjasama Dengan PG Madukismo. Yogyakarta.

Arifin, Bustanul, 2005. Ekonomi Kelembagaan Pangan, LP3ES Jakarta

Abidin, Z., 2000. Dampak Liberalisme Perdagangan Terhadap Keragaan Industri Gula Indonesia: Suatu Analisis Kebijakan. Disertasi Doktor. Program Pasca Sarjana, Institut Pertanian Bogor, Bogor. 
Pelaksanaan Usahatani Tebu Pasca Pencabutan Inpres....; Unggul Priyadi

Anwar, Affendi. 1995. Kajian Kelembagaan untuk Menunjang Pengembangan Agribisnis, Makalah Seminar. Bogor.

Anwar, Afendi dkk, 1992. Pengkajian Masalah Kebijksanaan Masalah pergulaan Nasional di Indonesia. Penelitian Kerjasama Sekretariat Badan Pengendali Bimas Departemen Pertanian dengan L P IPB Bogor

Arsyad, L. 2005. Institutions Do Really Matter: Important Lesson From Village Credit Institutions of Bali, jurnal Ekonomi dan Bisnis Indonesia. Yogyakarta. 20(2): 105 - 119.

Azhari, A. (2000). Kemitraan Agribisnis Tiga Tungku, Jurnal Ekonomi dan Disnis Indonesia. 15 (2): 186-200.

Binswanger, H.P. 1974. "A Cost Function Approach to the Measurement of Elasticities of Factor Demand and Elasticities of Distribution”.Amer J.Agr.Econ. 56:377-386.

Birowo, AT, Dibyo Prabowo, dan Poerwadi Djojonegoro, 1992. Perkebunan Gula. LPP, Yogyakarta.

Dianpratiwi, Trikuntarti, 1998. Unsur-unsur kemandirian industri gula di Jawa. Majalah Gula Indonesia 23(1): 46-49. P3GI. Pasuruan.

Erwidodo dan Susmiadi. 1996. Prospek pasar gula dunia. Majalah Gula Indonesia Vol. XXII/1 Januari-Maret 1997. P3GI. Pasuruan.

Fas Usda, 2001. Sugar: World markets and Trade. http://www.fas.usda.gov/

Frank.E, (2003). Peasant Economics, Bayu Media. Malang.

Gaspers, Vincent, 1991. Ekonometrika Terapan, Bandung: Tarsito

Ghozali,(2006), Aplikasi Analis Multivariate dengan program SPSS, Universitas Dipinegoro

Gittinger, J. Price, 1982. Economic analysis of agricultural projects. The John Hopkins University Press, Baltimore.

GUJARATI, D.N. 1988. Basic Econometrics. 2-nd ed. Mc Graw Hill Co. Singapore.

Gumbira,E,Rahmayanti, Zahrul.M, (2004). Manajemen Teknologi Agribisnis, Ghalia Indonesia. IPB

Gumbira. E, arizt.A,(2004). Manajemen Agribisnis, Ghalia Indonesia. IPB

Hadipuro, W. (2000). Kajian keberhasilan Kebijakan Kemitraan Usaha Besar-Menengah-Kecil, JEP. 5 (2): 1-12.

Hadipuro, W. , (1999), Kajian tentang Keberhasilan Kebijakan Kemitraan Usaha Besar, Menengah dan Kecil : Pengembangan Metodologi Evaluasi Kebijakan dan Penerapannya pada Program Tebu Rakyat Intensifikasi, Tesis Magister, Jurusan Teknik Industri, Institut Teknologi Bandung (Unpublished.

Hasibuan, Nurimansjah, 1986. Tantangan industrialisasi: proteksi dan keuntungan komparatif. Prisma 1, 1986: 14-32.

Hutabarat, et all. 1986. Strategies For Developing Sugar Industries In Indonesia: Resources Utilization And Technology Transfer. Makalah dalam The ISSCT XIX Congress di Jakarta 24-31 Agustus 1986. 
Ismail, N; Mahmudi, 2001. Jawaban jargon-jargon mengenai pergulaan nasional. Makalah dalam Rakernas (APTRI) di Cirebon 28 April 2001.

Ismoyowati, Dyah, (2004). Keuntungan dan Keunggulan Komparatif Usahatani Tebu sebagai Bahan Baku Industri Gula di Jawa. Disertasi pada UGM. Unpublished.

Ismoyowati,D; et all (1998). Keberadaan Industri Gula Di Jawa Dan Dukungan Sistem Usaha Tani Tebu Sebagai Bahan Baku Industri Sesudah Perubahan Kebijakan Pergulaan Tahun 1998, Agro Ekonomi.

James. C, Moral Ekonomi Petani, LP3ES.

Janvry,A.D; E. Sadoulet, 1995. Qoantitative Development Policy Analysis. The Johns Hopkins Univerity. London.

Kano, H; F. Husken, dan D. Surjo.1996. Di Bawah Asap Pabrik Gula Masyarakat Desa di Pesisir Jawa Sepanjang Abad Ke-20. Akatiga \& Gadjah Mada University Press.

Kasiram.M, (2008). Metodologi Penelitian Kualitatif-Kuantitatif, UIN Malang

Kholifah, Emy, 1995. Ekonomi politik perdagangan gula di Indonesia. Tesis pada Universitas Gadjah Mada. Unpublished.

Knutson, Ronald D., JB Penn, dan William T Boehm, 1990. Agricultural and food policy. Prentice Hall. New Jersey.

Koutsoyiannis, A. 1977. Theory of Econometrics, Harper Row Pub. Inc. New York.

Kraus, John, 1994. The GATT negotiations: a business guide to the results of the Uruguay Round. International Chamber of Commerce. Geneva. 